\title{
Managing and Measuring Business Networks in Russia*
}

\author{
Seppo E. Niittymäki, Lauri J. Tenhunen \\ HAMK University of Applied Sciences, Hämeenlinna, Finland
}

\begin{abstract}
The research topic of this article "Managing and measuring business networks in Russia" has been under consideration in three successive research projects oriented to Russian business to business (B2B) networks. The projects have been accomplished by HAMK, VTT Technical Research Centre of Finland, and Tampere University of Technology (TUT). Russian experts from The Higher School of Economics in Moscow and the Graduate School of Management in St. Petersburg were involved in these projects. We asked how managing and measuring B2B networks should be developed, when a company becomes established to Russian market. Both qualitative and quantitative analytical methods were used. Results concerning performance measurement presented in this article are based on data which was collected using survey and a questionnaire. Methodical triangulation was carried out as both research instruments produced 17 full answers for questions concerning performance measurement. Wider results are based on about 200 face-to-face interviews and answers for questionnaires. Results indicate that in Russia the management and leadership models as well as the company performance measurement should be adjusted to Russian traditions. Networked companies have difficulties in applying matrix type organizations in Russia, as management practices are based traditionally on authoritarian leadership. However, clear and specific targets should be set for projects and strategic business areas. Targets and bonuses should be agreed on with managers and staff throughout the company and the business network. Personal networks, within project stakeholders, have more emphasis in Russia than in Finland, because personal relations to authorities', and organizations are needed at every stage of the project. Therefore, managing SMEs working in B2B networks is challenging in Russia. In this article, a method for setting and implementing strategic targets for a business networked company is presented. Understanding networked performance measurement indicators will enable successful business for all networked partners in the long term.
\end{abstract}

Keywords: managing, measuring performance, business networks, Russia

\section{Special Character of Russian Business Environment}

The results presented in this paper have been produced by three successive research projects, "Profiling Business Networks Oriented to Russia”, "STROI-Network" and "ROCKET” during the years 2006-2012. The projects have been accomplished predominantly by HAMK, having also VTT and TUT as domestic partners in

\footnotetext{
* Acknowledgements: TEKES - the Finnish Funding Agency for Technology and Innovation (2006-2009) and also Regional Council of Päijät-Häme by applying the South Finland ERDF Programme allocation for ROCKET-project (2010-2012).

Seppo E. Niittymäki, Lic. of Techn., Principal Lecturer, Education and Research Centre for Technology, HAMK University of Applied Sciences.

Lauri J. Tenhunen, Dr. of Sci., Principal Lecturer, Education and Research Centre for Technology, HAMK University of Applied Sciences.

Correspondence concerning this article should be addressed to Seppo E. Niittymäki, Visamaentie 35 B, 13100 Hameenlinna, Finland. E-mail: seppo.niittymaki@hamk.fi; lauri.tenhunen@hamk.fi.
} 
the projects. Many of the results of this paper have been produced together with the Russian experts from The Higher School of Economics in Moscow and the Graduate School of Management in St. Petersburg.

Business to business (B2B) networked companies in construction and other technically oriented business seem to have extreme difficulties in applying matrix type organizations in Russia, as Russian management practices are based traditionally on strong and authoritarian leadership. According to the interviews, clear and specific targets should be set to any intended activity like projects, as well as strategic business areas. The targets and bonuses should be agreed with managers and staff throughout the company. The results suggest that the targets need to be set to the business network as well (see Figure 1). In Russia, both leadership and personal networks within project stakeholders have more emphasis than in Finland.

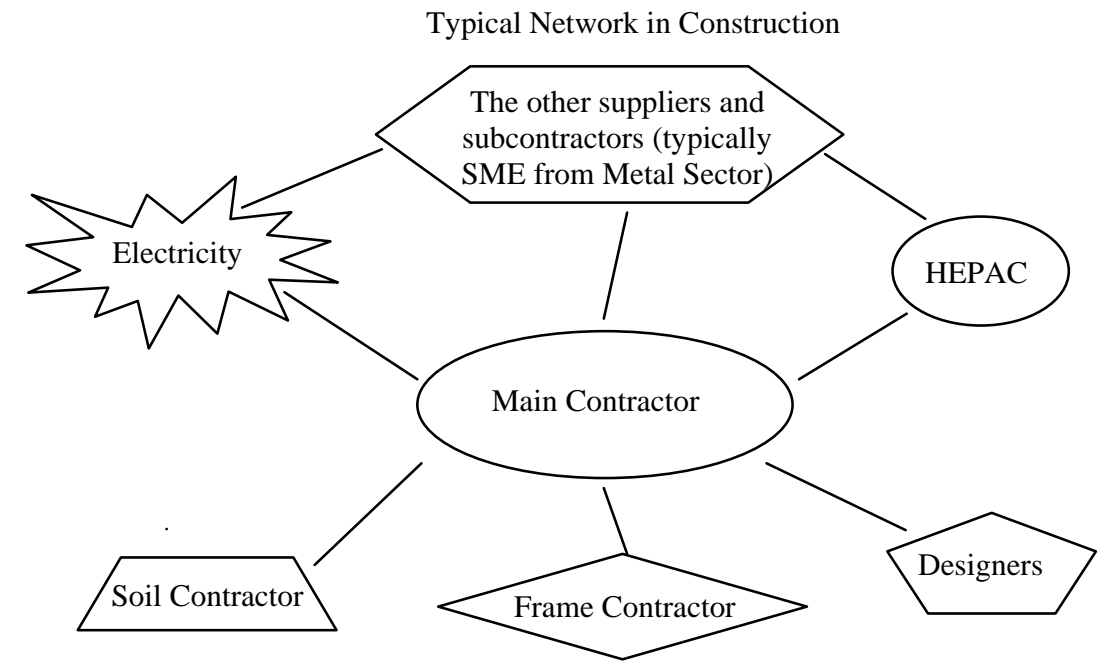

Figure 1. Typical network in construction business (Niittymäki, 2010).

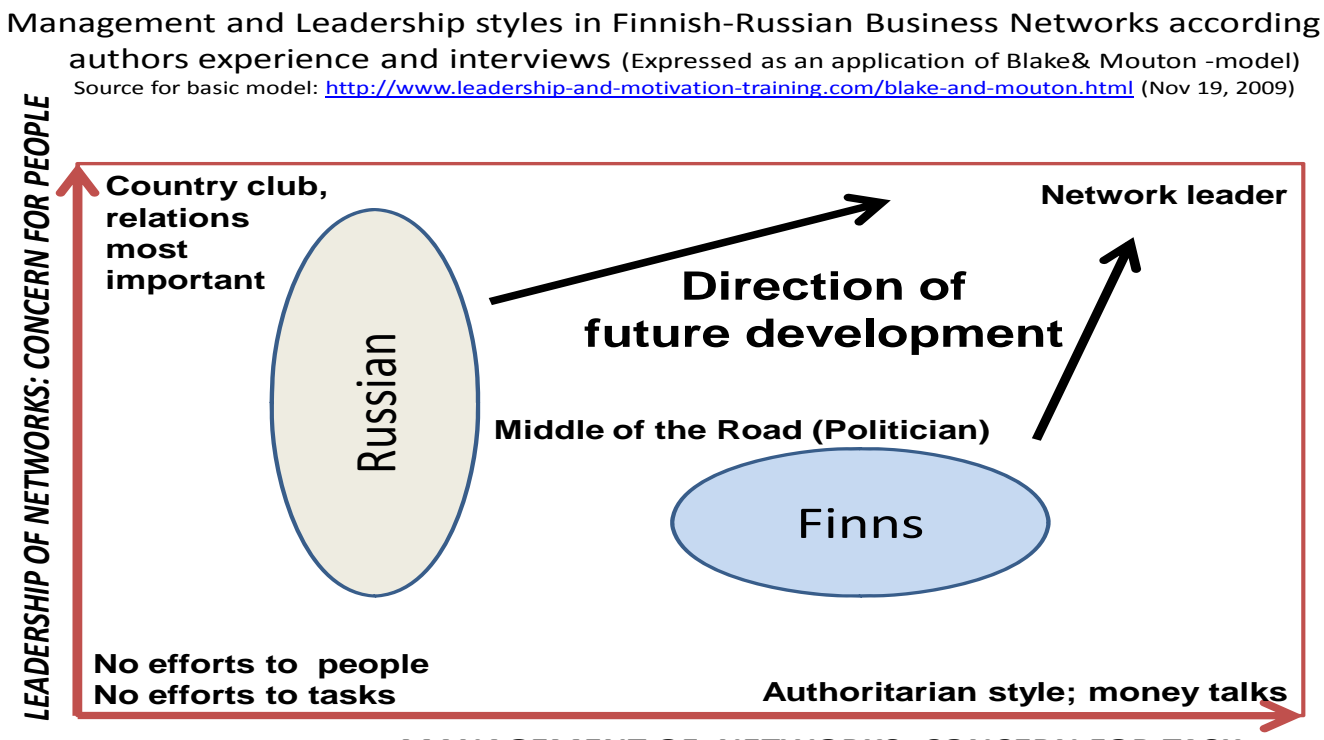

MANAGEMENT OF NETWORKS: CONCERN FOR TASK

Figure 2. Development needs of management and leadership in Finnish Russian business networks (Based on the authors' experience and discussions during interviews as well as the Blake and Mounton model for task and people orientation). 
Especially in versatile activities like a construction project, personal relations to authorities' organizations are needed at every stage. All the facts above mean that in Russian projects, business management and leadership models should be adjusted to the Russian tradition and business culture. This yields to company performance measurement indicators as well.

Traditionally strategic planning and strategy implementation may be carried out with numerical models (described below), by setting measurable targets for each dimension. Many issues will affect target setting: Results from the previous years, the country in question, and the political, economic, sociological, technological and environmental situation (PESTE) and the development of these factors in the future.

The Russian situation is more complicated: The political, economic, sociological, technological, and environmental situation is different compared to western models and partly unpredictable as well. Also, the business culture is totally different: The power (and the responsibility) is strongly concentrated to the main director of a company even according to Russian law. The tradition in Russia supports strong and authoritarian leadership. In Russia former acquaintances are highly appreciated as a part of business culture as well as in common life (Salmi, 2006). According to the author's experience and results of interviews among SMEs and Multinational Companies (MNC), Finnish and Russian Management and Leadership styles differ quite much: Finnish managers emphasize task orientation and Russians concentrate on people and relations within networks (see Figure 2).

\section{From Balanced Score Card to Network Score Card}

The importance of the network culture and resources in the planning strategy were also indicated in the interviews (see Figure 3).

\section{From Balanced Score Card (BSC) to Network Score Card (NSC)}

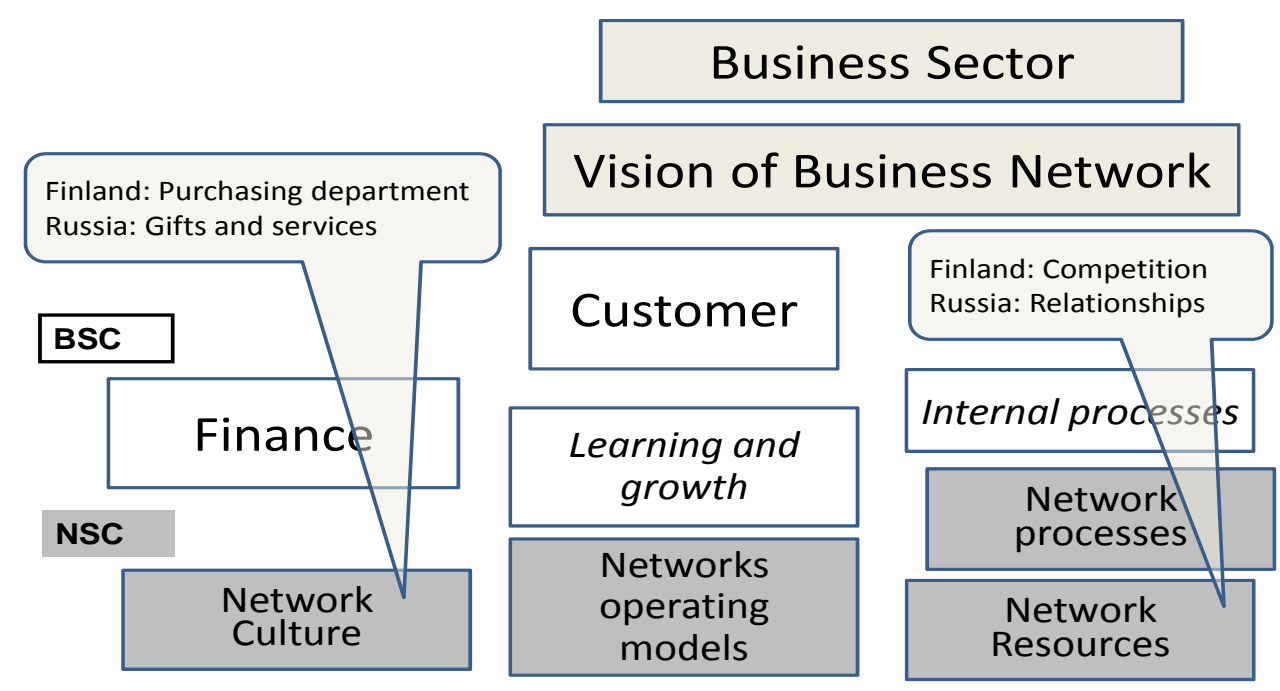

Figure 3. From company balanced score card (BSC) to network score card (NSC).

\section{A Model for Strategic Planning and Strategy Implementation}

The planning strategy in project based businesses depends on various perspectives considered and the expectations about their future development. Perspectives (P1-P6) and factors of business environment are described below (see Figure 4). 


\section{A Model for Planning and Implementing Strategy in Project Business}

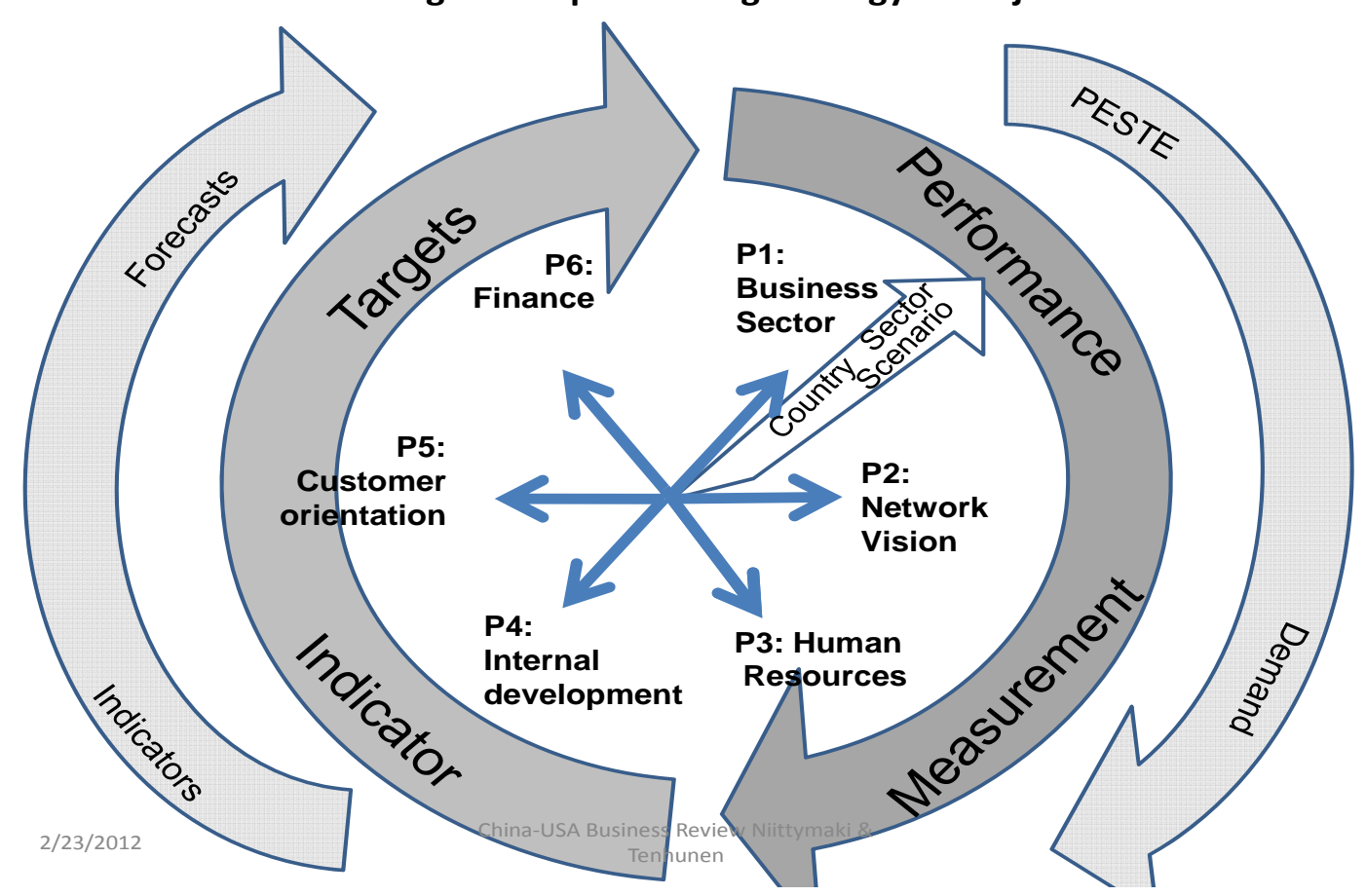

Figure 4. A model for planning and implementing strategy in business networked companies. In the SME metal sector, project business is the prevailing way of business.

The most important perspectives are:

- P1: The business sector and country;

- P2: A successful vision for the company and the business network;

- P3: The ways of managing human resources within companies and the business network;

- P4: Internal development and learning within the network;

- P5: Keeping up customer orientation;

- P6: Setting measurable financial and other targets within companies and the business network.

The implementation of the strategy will be possible, if the targets are set and agreed in the network in an understandable way (for every actor in the network) and people understand their objectives and responsibilities within the project business in question. Performance measurement indicators for each perspective should point towards common targets of the network in order to implement the necessary change on the ways of action as soon as possible (see Figure 4).

\section{Performance Measurement in Business Networks in Russia and Finland}

Multinational companies (MNC) in construction seem to have implied their strategy and performance measurement successfully, as many of these have rewarded their owners with excellent dividends and many of these companies belong to preferred employers among young graduates. Actually, these companies are working like huge networks, as from $50 \%-70 \%$ of their turnover consists of purchases from other companies or SMEs. The model described below has been derived from practices of several MNCs which are working in Russia (see Figure 5). The model is a base to develop performance measurement indicators (PMI) and strategy implementation tools for the SMEs working in the metal industry and/or the construction business in Russia. 


\section{Common Dimensions of Performance Measurement}

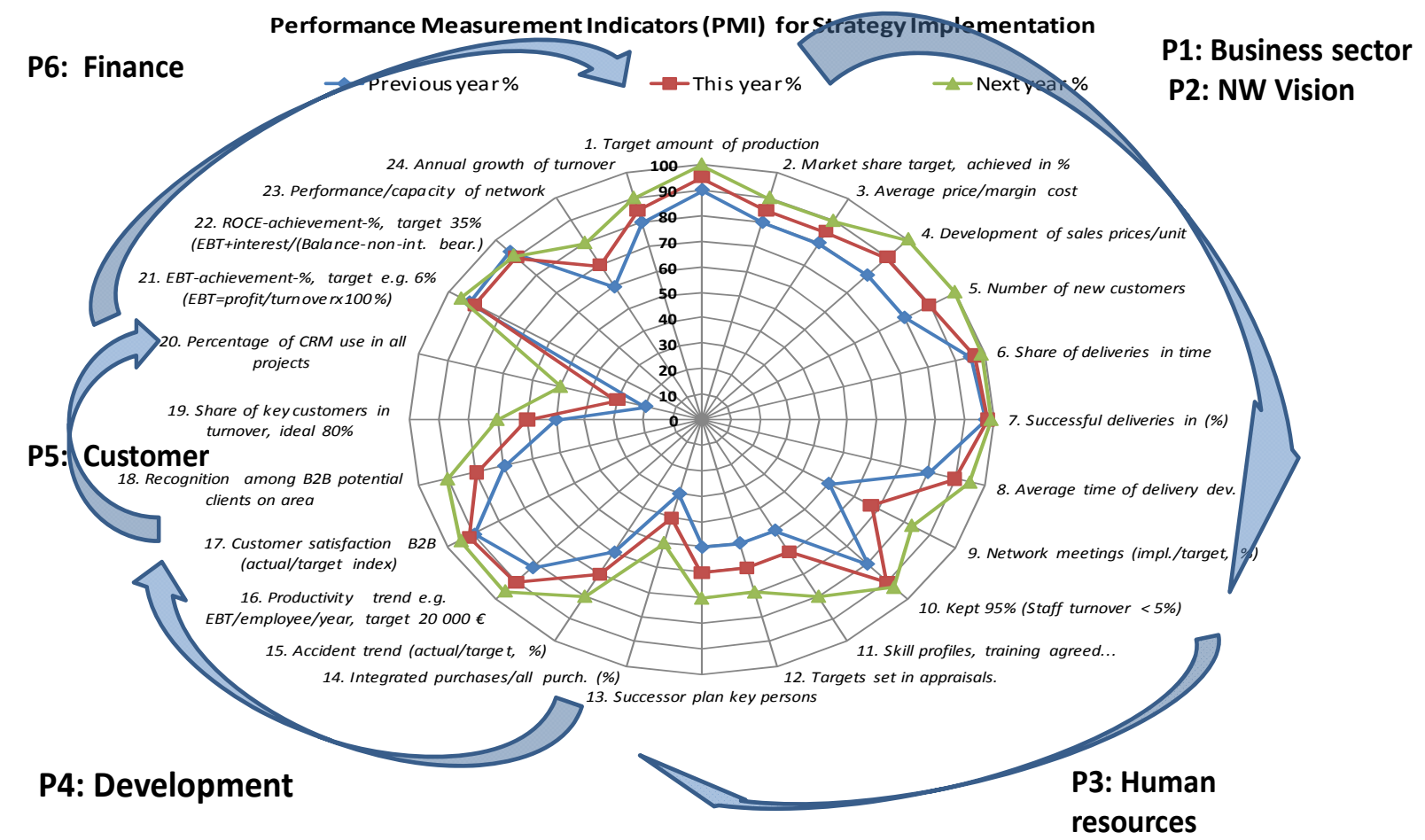

Figure 5. Performance measurement indicators (PMI) of a business networked company or SMEs for strategy implementation. The description comes from combining dimensions used in Finnish companies (Niittymäki et al., 2009). The model is available on the web-site http://www.hamk.fi/stroi.

Figure 5 shows how the original 24 measured and tested dimensions are classified into the most important groups of measures, given in Figure 4. The relations between the SMEs as suppliers on one hand and the subcontractors on the other hand, have been taken into account in the original dimensions 6, 7, 8 and 9.

Even the MNC directors feel that the originally measured dimensions have too many aspects to follow and therefore they asked us to find out the most relevant dimensions to set targets and to follow them up. A survey (eight management level answers) and a series of interviews (nine management level answers) were carried out to find out the most important dimensions. This is what we have described in Figure 6.

In addition to the mentioned six indicators, we also found nine indicators which are almost as important as the mentioned six above (see Figure 7). The importance of work safety has increased significance on SME metal sector companies.

The list of the most important perspectives (P1-P6) and factors to be measured and followed in business networks are presented in Table 1.

\section{Application in Finland and Russia}

The application of performance measurement indicators in Finland and Russia should be different. In Russia the position of the main director is different compared to Finland. For the main Russian director there should be adequate resources in order to carry out all duties for Russian authorities and Finnish headquarters. An implementation of applied management systems will therefore imply remarkable training efforts for Finnish 
and Russian staff members. Measuring only key financial indicators is not any more adequate, but also measuring indicators for other perspectives should be created.

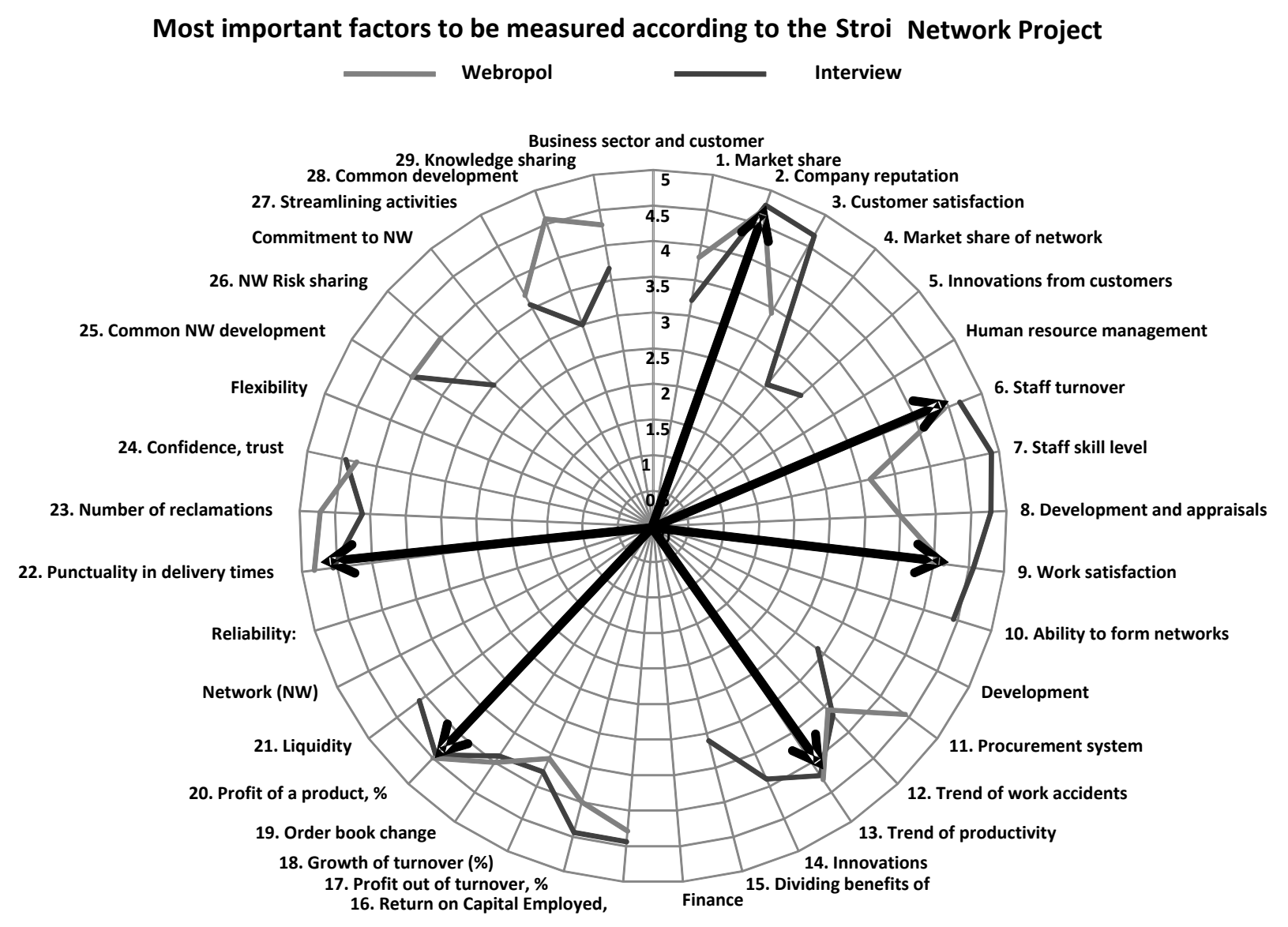

Six most important factors for each perspective

Figure 6. The six most important factors (PMI, Performance Measuring Indicators) within SME business networks. In this figure the importance of measuring innovations is underestimated, as a tradition to measure innovations not exist. At least does one performance measurement indicator (PMI) should be selected for the following perspectives: (1) Business sector; (2) Customer; (3) Human resources; (4) Development and productivity; (5) Finance and as well; (6) Network confidence and flexibility.

Improving staff innovation abilities and initiatives will be challenging in Russia, as this has not been appreciated within local companies earlier. The starting point for adopting the learning organization concept could be development discussions (appraisals). During appraisals development and learning targets as well as possible bonuses can then be agreed upon.

\section{Conclusions and Future Objectives}

Finnish companies and business networks seem to rely on matrix type organizations. The learning organization is quite well known in Finnish organizations at management level. Finnish companies and business networks have some difficulties in planning and implementing their strategies in Russia, not only due 
to the present financial crisis. In Russia, management tradition and practice are different compared to Finland: authoritarian management and leadership style is prevailing; staff development discussions (appraisals) are not well understood and applied.

\section{Most important factors to be measured according to the Stroi Network Project}

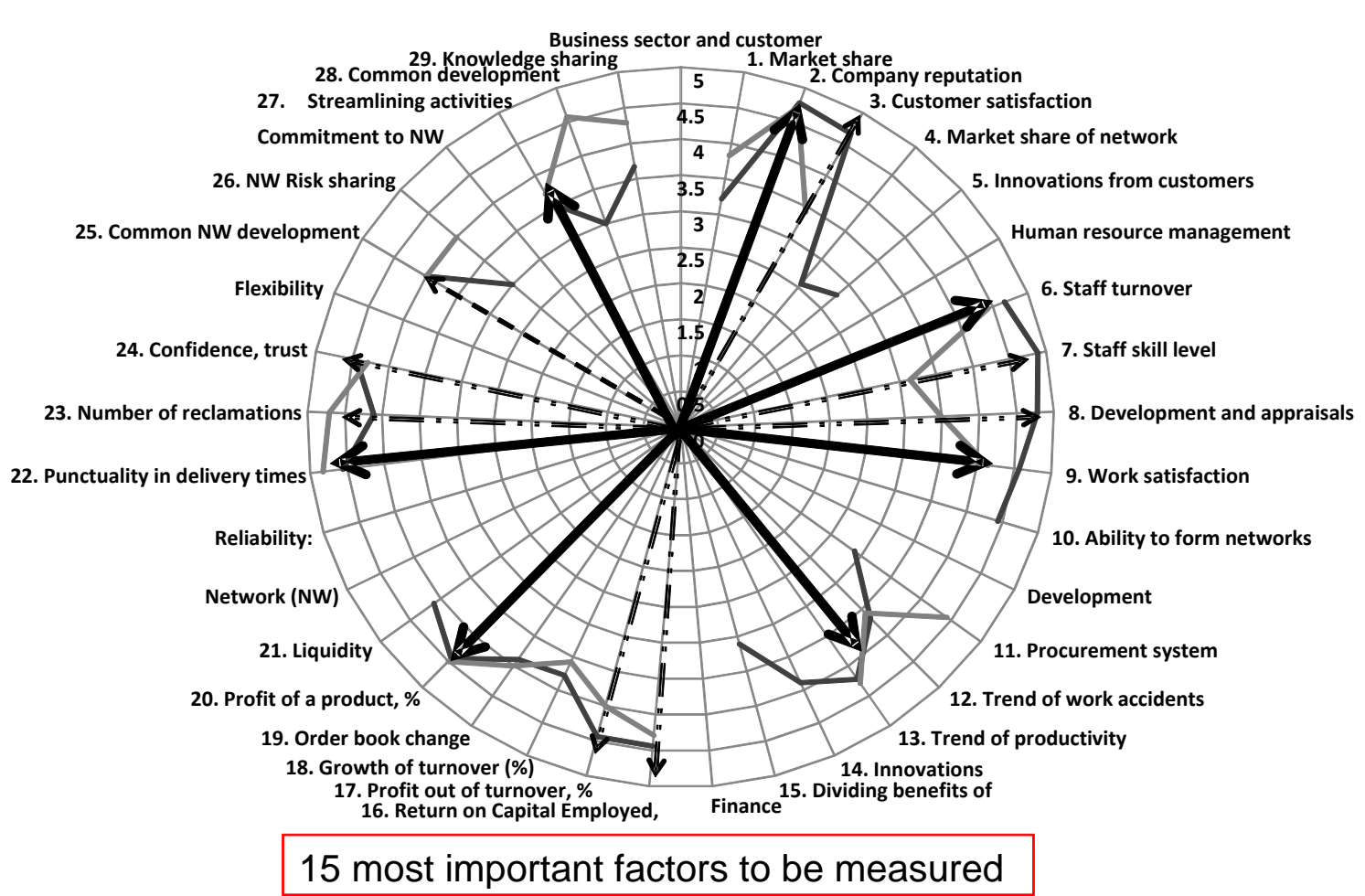

Figure 7. The most important factors to be measured within business networks. Items 25. Common development and 27. Streamlining activities are combined later on.

Table 1

The Most Important 15 Factors to be Measured in Different Perspectives (P1-P6). Emphasis Based on SMEs in Metal Industry

\begin{tabular}{|l|l|l|l|}
\hline Perspective & Factor to be measured & Perspective & Factor to be measured \\
\hline P1: Business sector & 1 company reputation & P4: Internal development & 9 trend of productivity \\
\hline P2: Network aspects & 2 punctuality of delivery times & & 10 work safety \\
\hline & 3 number of reclamations & P5: Customer orientation & 11 growth of turnover \\
\hline & 4 confidence within network & & 12 order book change \\
\hline & $\begin{array}{l}5 \text { common development and } \\
\text { streamlining activities }\end{array}$ & & 13 profit of a product \\
\hline P3: Human resources & 6 staff turnover & P6: Finance & 14 return on capital employed \\
\hline & 7 work satisfaction & & 15 profit \\
\hline & 8 staff skill level development & & \\
\hline
\end{tabular}

Clear and specific targets should be set for projects as well as to the strategic business areas. The targets and bonuses should be agreed with managers and staff throughout the company, and the business network. In Russia, both leadership and personal networks within project stakeholders have more emphasis than in Finland, 
because personal relations to authorities' organizations, for example, are needed at every stage of the construction project. The most important perspectives (P1-P6) and factors to be measured within business networks, which should have target values for the next two years, are the following:

P1: Business sector: (1) company reputation;

P2: Network aspects: (2) punctuality of delivery times; (3) number of reclamations; (4) confidence within network; and (5) common development and streamlining activities;

P3: Human resources: (6) staff turnover; (7) work satisfaction; and (8) staff skill level development and appraisals;

P4: Internal development: (9) trend of productivity; and (10) work safety;

P5: Customer orientation: (11) growth of turnover; (12) order book change; and (13) profit of a product;

P6: Finance: (14) return on capital employed; and (15) profit.

However, the method of application in Finland and Russia should be different. In Russia the position of the general director is strong compared to Finland where visions and such soft methods are used more frequently. For the main Russian director there should be adequate resources in order to carry out all duties for Russian authorities and Finnish headquarters. An implementation of applied management systems will entail remarkable training efforts for Finnish and Russian staff members. Improving staff innovation abilities and initiatives will be challenging in Russia, as this has not been appreciated within the local companies earlier. The starting point for adopting a learning organization concept could be usable in development discussions (i.e., appraisals). During appraisals development and learning targets as well as possible bonuses should be agreed upon.

\section{References}

Ansoff, H. I. (1979). Strategic management (Classic ed.). Palgrave Macmillan.

Denzin, N. K. (1970). The research act in sociology. Chicago: Aldine.

Denzin, N. K. (1978). Sociological methods: A sourcebook. N.Y.: McGrawHill.

Doz, Y., \& Kosonen, M. (2008). Fast strategy: How strategic agility will help you stay ahead of the game. Wharton School Publishing.

Kaplan, R. S., \& Norton, D. P. (2004). Strategiakartat: Aineettoman pääoman muuttaminen mitattaviksi tuloksiksi. Talentum

Kaplan, R. S., \& Norton, D. P. (2007). Strategian toteutus. Talentum.

Kasanen, E., Lukka, K., \& Siitonen, A. (1991). Konstruktiivinen tutkimusote liiketaloustieteessä. Liiketalouden Aikakauskirja 3 , 301-327.

Niittymäki, S. (2009). Towards management and leadership models for Russian business networks. In K. Kähkönen, A. S. Kazi, \& M. Rekola (Eds.), The human side of projects in modern business (pp. 255-267). Scientific Research Paper Series. IPMA, International Project Management Association.

Niittymäki, S. (2010). Performance measurement in business. Presentation at the XI HSE International Academic Conference on Economic and Social Development Problems sponsored by The State University-Higher School of Economics with support of the World Bank and the International Monetary Fund, March 8th, 2010.

Niittymäki, S., \& Tenhunen, L. (2011). Managing and measuring business networks in Russia. Combi 2011 Conference Proceedings. HAMK University of Applied Sciences.

Niittymäki, S., Tenhunen, L., Weck, M., Lod, T., Tolonen, T., Kähkönen, K., ... Vladimirova, N. (2010). STROI-network-business networks in Russia Final report 2009. HAMK University of Applied Sciences. HAMK in e-julkaisuja 3/2010.

Salmi, A. M. (2006). Social networks and everyday practices in Russia. Gummerus Printing.

Tenhunen, L., \& Niittymäki, S. (Eds.). (2011a). ROCKET—hanke, väliraportti 1. HAMK University of Applied Sciences. HAMK publications $1 / 2011$.

Tenhunen, L., \& Niittymäki, S. (Eds.). (2011b). ROCKET—hanke, väliraportti 2. HAMK University of Applied Sciences. HAMK publications 3/2012. 